\title{
Relative Population Density of the House Mouse in Poland: an Analysis of Owl Pellets
}

WZGLEDNE ZAGESZCZENIE POPULACJI MYSZY DOMOWEJ W POLSCE: ANALIZA
ZRZUTEK SOW

\section{Andrzej L. RUPRECHT}

\begin{abstract}
Ruprecht A. L., 1986: Relative population density of the house mouse in Poland: an analysis of owl pellets. Acta theriol., 30, 14: 176-179 [With 2 Figs.]

The relative density of the house mouse in Poland was estimated on the basis of the percentage it formed in 938 collections of owl pellets from the period $1955-1971$, in squares of the $50 \times 50 \mathrm{~km}$ UTM grid. Regions situated to the west of the River Vistula are characterized by low and medium density of the house mouse. High and very high density of $M$. musculus was found in the Pomeranian Lake District (square CE), Masovian Lowland (DC) and Sandomierz (EB) and Lublin (FB) Uplands. In these areas the house mouse predominates in the composition of owls' food, and this is usually accompanied by a low percentage of the common vole. The relation between these two species of rodent in owls' diet is inverse and is expressed by the coefficient of correlation $r=-0.4965$.
\end{abstract}

[Mammals Research Institute, Polish Academy of Sciences, 17-230 Białowieża, Poland]

\section{INTRODUCTION}

There are relatively few data on the house mouse (e.g. Schmidt, 1971; Berry, 1981) to be found in the considerable amount on population density of small mammals (e.g. Smith 'et al., 1975). In Poland examination was made only of geographical differences in the percentages of representatives of Muridae and Microtidae in the composition of owls' food (Sałata-Piłacińska, 1977). The purpose of the present study was to ascertain the relative population density of the house mouse in Poland and to examine the degree of its regional differences.

\section{MATERIAL AND METHODS}

The material used consisted of 938 single and seasonal collections of the barn owl's pellets (Tyto alba guttata (C.L.Br.), accumulated from 1955-1971 by the Mammals Research Institute, PAS, at Białowieża and the Institute of Systematic Zoology, A. Mickiewicz University in Poznan, forming a joint total of 474,436 remains of individual small vertebrates. The percentage formed by the house mouse in the given collection was calculated in relation to the total numbers of small vertebrates taken as $100 \%$. There was a very small addition in the form of collections of the tawny owl's pellets, and those of the long-eared owl and little owl, taken from Polish literature on the subject.

The Universal Transverse Mercator grid was used, taking as a unit a square with $50 \mathrm{~km}$ sides, within which the average density of the house mouse was calculated by averaging its percentages in collections from localities situated 
within the square. The number of collections containing house mice for a standard area of $2.500 \mathrm{~km}^{2}$ varied from $1-82$. More than half $(50.8 \%)$ was formed by squares from which between 2 and 5 collections containing remains of $M$. musculus originated, whereas squares numbering 63 and 82 collections were rare, and formed only $0.8 \%$ of the whole material.

The following scale of relative density of the house mouse was employed: $0-19 \%$ - low, $20-39 \%$ - medium, $40-49 \%$ - high, $50 \%$ or over - very high.

\section{RESULTS}

Areas to the west of the Vistula are characterized by low and medium density of the house mouse, but as from squares XV and XU the average density of $M$. musculus increases in an eastwards direction. The groups of squares $\mathrm{CE}, \mathrm{DC}, \mathrm{EB}$ and $\mathrm{FB}$ are distinguished by high and very high density of the house mouse, i.e. in the Pomeranian Lake District (CE), Masovian Lowland (DC) and the Sandomierz (EB) and Lublin Uplands (FB) - Fig. 1. This averagely high density of the house

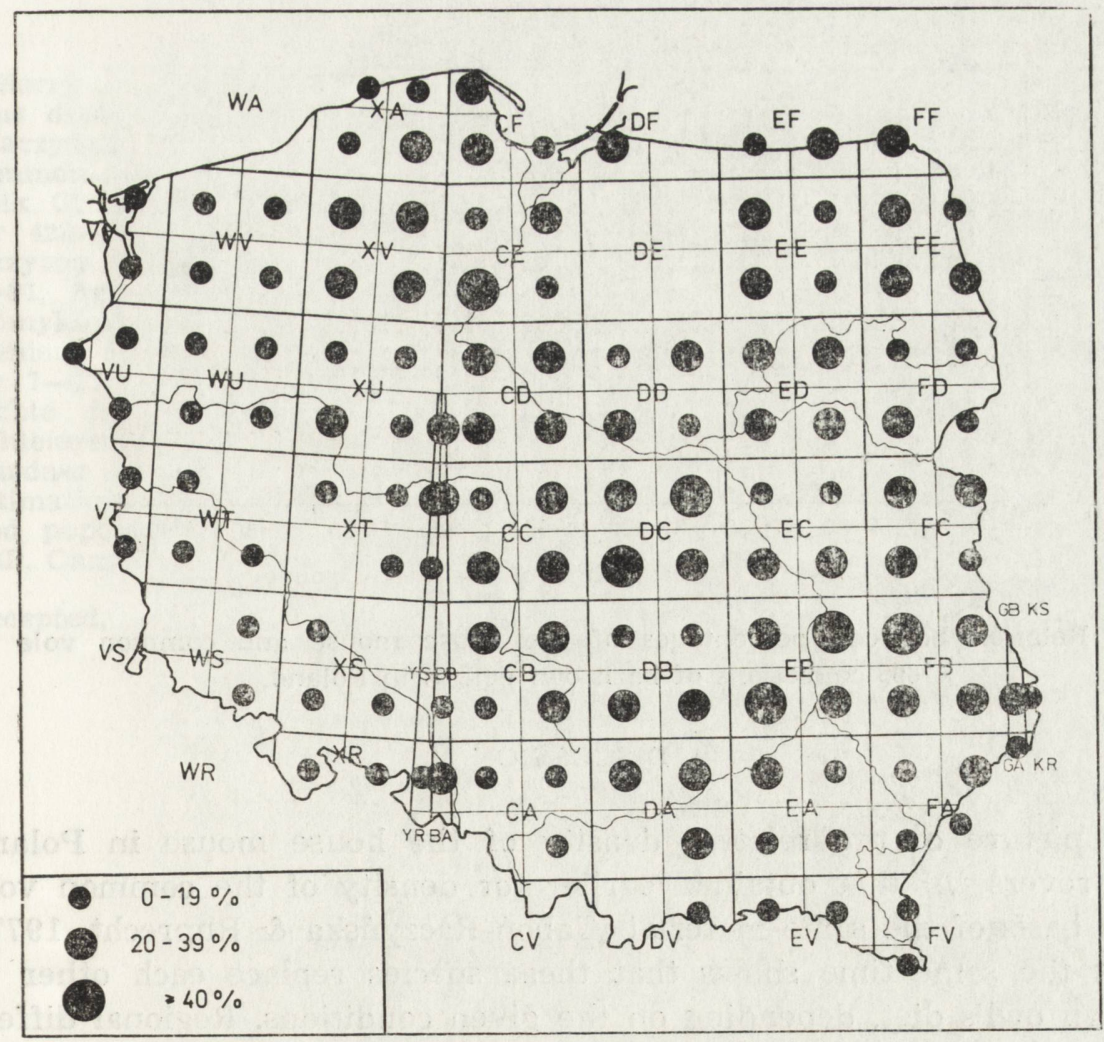

Fig. 1. Relative density of the house mouse in Poland as expressed by its average percentage in owl pellets collections. 
mouse is indirect evidence of its numerous occurrence in these areas, and of its forming (despite seasonal fluctuations) a basic component of owls' food.

The relation between the percentage of the house mouse and common vole in 695 collections of barn owl pellets is an inverse one, and is expressed by a significant coefficient of correlation: $r=-0.4965(p<$ $<0.001)-$ Fig. 2.

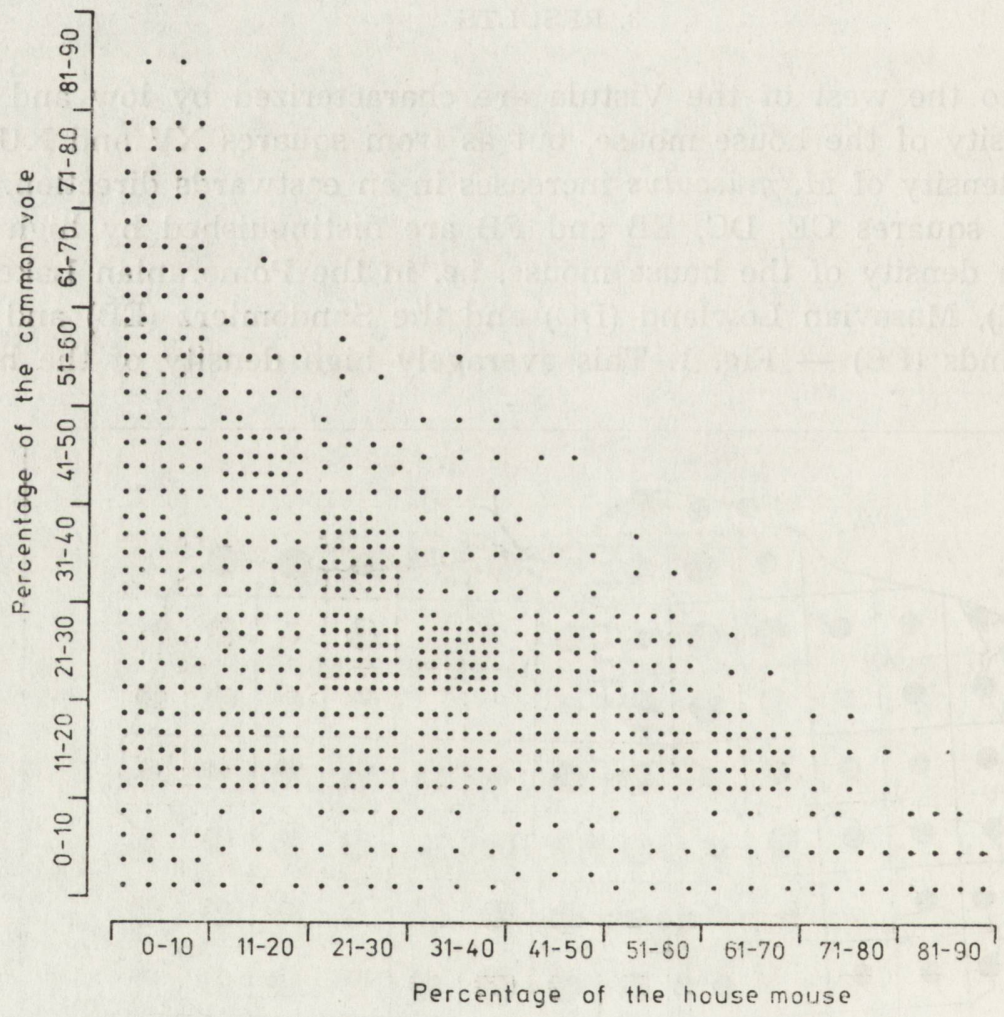

Fig. 2. Relation between percentages of the house mouse and common vole in 695 collections of barn owl pellets in Poland.

\section{DISCUSSION}

The picture of the relative density of the house mouse in Poland is the reverse of that obtained earlier for density of the common vole on the basis of the same material (Cabon-Raczyńska \& Ruprecht, 1977), and at the same time shows that these species replace each other in the barn owl's diet, depending on the given conditions. Regional differences in the density of the house mouse in Poland is due to the varying level of agricultural practice and the different agrarian structure of 
cultivated land (Sałata-Piłacinska, 1977), the varying sanitary state of human settlements (Nikodem, 1974) and the current population numbers of this rodent. The density of the house mouse may vary markedly depending on local conditions, but there are no data available on this subject for Poland. Usually the cause of an explosive increase in population numbers are mild winters, after which the large number of animals surviving begin reproducing (Berry, 1981). The results obtained by model experiments aimed at definiting the basic population parameters in studies on variations in population dynamics of small mammals point to the fact that estimates obtained from analysis of owl pellets are more reliable than those obtained from trapping carried out parallel to collections (Fulk, 1976). Thus apart from any possible error affecting the results presented here, it may be concluded that when the relative density of house mice in Poland is examined in this way, the results very accurately reflect the true state of relations in the area.

\section{REFERENCES}

Berry R. J., 1981: Town mouse, county mouse: adaptation and adaptability in Mus domesticus (M. musculus domesticus). Mammal Rev., 11: 91-136. - Caboń-Raczyńska K. \& Ruprecht A. L., 1977: Estimation of population density of the common vole in Poland: an analysis of owl pellets. Acta theriol., 22: 349-354. Fulk G. W., 1976: Owl predation and rodent mortality: a case study. Mammalia, 40: 423-427. - Nikodem Z., 1974: Badania nad fauną drobnych ssaków Lubelszczyzny w aspekcie sezonowym na podstawie analizy zrzutek sów. Ph. D. Thesis: 1-91, Agricult. Acad., Wrocław. - Sałata-Piłacińska B., 1977: Ssaki w pokarmie płomykówki (Tyto alba guttata Brehm) z terenu Polski, ze szczególnym uwzględnieniem zachodniej części kraju. Badan. fizjogr. Pol. zachod., Ser. C - Zoologia, 30: 7-27. - Schmidt E., 1971: Uber die geographische Verbreitung und Wohndichte der Hausmaus (Mus musculus L.) in Europa nach Gewöllanalysen von Schleiereulen (Tyto alba Scop.). Z. angew. Zool., 57: 137-143. - Smith M. H., Gardner R. H., Gentry J. B., Kaufman D. W. \& O'Farrell M. H., 1975: Density estimations of small mammal populations. In: Small mammals: their productivity and population dynamics. Petrusewicz K., Golley F. B. \& Ryszkowski L., (Eds). IBP, Cambridge University Press, Vol. 5: 25-63. 